\title{
Bed load transport in alluvial channels
}

\author{
BY \\ RAM J. GARDE \\ LECTURER IN CIVIL ENGINEERINA \\ (FLUID MECHANICS), \\ UNIVERSITY OF ROONKEE, ROORKEE (INDIA) \\ AND \\ M. L. ALBERTSON \\ PROFESSOR OF CIVIL ENGINEERING \\ AND DIRECTOR OF RESEARCH FOUNDATION, \\ COLORADO STATE UNIVERSITY, FORT COLLINS (U.S.A.)
}

Texte français p. 282 The available bed-load data reanalysed and
it is shown that the laws of bed-load transport
are much dependent on the bed condition.
Separate functional relationships are given for the plane-bed condition and the dune-bed condition. The relationships proposed are quite simple to use.

\section{INTRODUCTION}

For several reasons, it is of interest to the hydraulic and irrigation engineers, to know the total amount of sediment that is transported by an alluvial channel, for the given hydraulic characteristics. According to the method of transportation, the total load can be sub-divided into suspended load, saltation load, and contact load. Contact load is the material rolled or slid along the bed in substantially continuous contact with the bed. Saltation load is the material bouncing along the bed, or moved, directly or indirectly by the impact of bouncing particles. Suspended load is the material moving in suspension in the fluid. In most of the cases, saltation load is very small and furthermore it is difficult to draw a line of distinction between saltation load and contact load. For these reasons, (saltation load + contact load) will be taken as bed load.

Various attempts have been made since 1879 to establish methods for evaluating the bed load transport. Bed load equations of Du Boys, Shields, Chang, McDougall and O'Brien, MeyerPeter, Kalinske, Einstein, and the others are the result of such attempts. These equations can be divided into two broad categories : a) Empirical equations of Chang, McDougall and O'Brien, Meyer-Peter, and such other's;

b) Semi-theoretical equations of Du Boys, Shields, Kalinske, Einstein and such others.

\section{Comparison of Meyer-Peter, Kalinske, and Einstein equations.}

In spite of the fact that all these equations take different forms, it is quite interesting to note that most of these equations can be expressed in a general form:

$$
\frac{q_{\mathrm{B}}}{\mathrm{V}_{*} \gamma_{s} d,}=f\left(\frac{\tau_{0}}{\left(\gamma_{B}-\gamma_{f}\right) d}\right)
$$

or substituting

$$
\tau^{*}=\frac{\tau_{0}}{\left(\gamma_{s}-\gamma_{f}\right) d} \text { and } q^{*}{ }_{\mathrm{B}}=\frac{q_{\mathrm{B}}}{\mathrm{V}_{*} \gamma_{s} d} \text { one gets }
$$

in which

$$
q^{*}{ }_{\mathrm{B}}=f\left(\tau^{*}\right)
$$


$\tau_{0}$ is the average shear stress on the bed,

$q_{\mathrm{B}}$ is the rate of bed load transport in weight per unit width of the channel per unit time,

$d$ is the mean size of the bed material,

$V_{*}$ is the shear velocity $\left[=\sqrt{\left(\tau_{0} / \rho_{f}\right)}\right.$,

$\rho_{f}$ is the mass density of the fluid, and

$\because s, \gamma_{f}$ are the specific weights of sediment and water resp.

Thus, for example, consider Meyer-Peter's equation [1] :

$$
\varphi=\left(\frac{4}{\psi}-0.188\right)^{3 / 2}
$$

in which :

$$
\psi=\frac{\rho_{\varepsilon}-\rho_{f}}{\rho_{f}} \cdot \frac{d}{\mathrm{RS}},
$$

$R$ being the hydraulic radius, $S$ the slope of energy line and $\rho_{s}$ the mass density of sediment, and :

$$
\varphi=\frac{q_{\mathrm{B}}}{\gamma_{s}}\left(\frac{\rho_{\ell}}{\rho_{s}-\rho_{f}}\right)^{1 / 2}\left(\frac{1}{g d^{3}}\right)^{1 / 2} .
$$

One can express $\psi$ and $\varphi$ in the following way :

$$
\begin{aligned}
\psi=\frac{\rho_{s}-\rho_{f}}{\rho_{f}} \frac{d}{\mathrm{RS}} & =\frac{g\left(\rho_{s}-\rho_{f}\right)}{g_{\rho_{f}}} \frac{d}{\mathrm{RS}} \\
& =\frac{\left(\gamma_{s}-\gamma_{f}\right) d}{\tau_{0}}=\frac{1}{\tau^{*}},
\end{aligned}
$$

and :

$$
\begin{aligned}
\varphi=\frac{q_{\mathrm{H}}}{\gamma_{s}}\left(\frac{\rho_{f}}{\rho_{s}-\rho_{f}}\right)^{1 / 2}\left(\frac{1}{g d^{3}}\right)^{1 / 2} & \\
& =\frac{q_{\mathrm{B}}}{\mathrm{V}_{* \gamma_{s}} d} \cdot \frac{\mathrm{V}_{*} d_{\rho_{f}^{1 / 2}}}{\left(\rho_{s}-\rho_{f}\right)^{1 / 2}} \cdot\left(\frac{1}{g d^{3}}\right)^{1 / 2} .
\end{aligned}
$$

Hence :

$$
\varphi=q_{\mathrm{B}}^{*} \tau^{* 1 / 2} .
$$

Substituting these values of $\psi$ and $\varphi$ in equation (2) one gets the Meyer-Peter equation in the form :

$$
q^{*}{ }_{\mathrm{B}} \tau^{* 1 / 2}=\left(4 \tau^{*}-0.188\right)^{3 / 2} .
$$

Einstein's bed-load equation, for the case of uniform bed material, can be written in the following form :

$$
\varphi=f(\psi),
$$

in which $\varphi$ and $\psi$, are as defined previously. But, since $\varphi$ and $\psi$ can be expressed in terms of $q^{*}{ }_{\mathrm{B}}$ and $\tau^{*}$, Einstein's equation of bed-load can be written in the form :

$$
q^{*}=f\left(\tau^{*}\right) .
$$

Finally, Kalinske's bed load equation [8] can be written as,

$$
\frac{q_{\mathrm{B}}}{\mathrm{V}^{*} \gamma_{s} d}=f\left(\frac{\tau_{0}}{\tau_{0}}\right)
$$

in which $\tau_{c}=12 d$. Therefore, equation (7) can also be put in the form :

$$
q^{*}{ }_{B}=f\left(\tau^{*}\right) \text {. }
$$

Instead of studying separately the behaviour of all these three equations with respect to certain data, the writers plotted these equations with $\eta^{*}{ }_{B}$ and $\tau^{*}$ as the two axes. Such a plot is also given by Iwagaki [6] and by Rouse (9], even though the latter has presented it in a slightly different way.

\section{Further comments on Einstein's equation.}

Einstein $[2,3]$ divided the average shear on the bed, $\tau_{0}$, into two parts :

$$
\tau_{0}=\tau_{0}^{\prime}+\tau^{\prime \prime}{ }_{0}
$$

in which :

$0_{2} 2$ is the shear stress which would result from the grain resistance alone, on the plane bed; and

$\tau^{\prime \prime}{ }_{0}$ is the additional shear stress due to irregularities on the bed-such as dunes and sandbars.

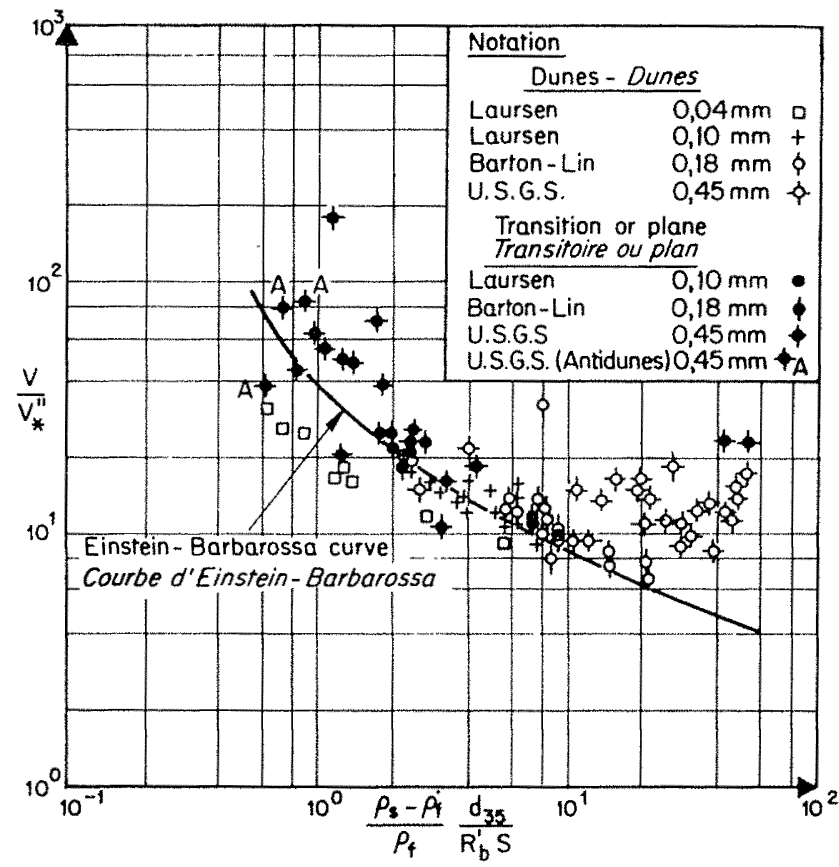

FIG. 1

Variation of $V / V^{\prime \prime}$, with $\left(Q_{s}-Q_{0}\right) / Q_{Q r} \cdot\left(d_{35} / R^{\prime}{ }_{b} S\right)$.

Variation de $\mathrm{V} / \mathrm{V}^{\prime \prime}$ * avec $\left(\mathrm{Q}_{s}-\mathrm{Q}_{\mathrm{f}}\right) / \mathrm{Q} \cdot\left(\mathrm{d}_{3 \mathrm{j}} / \mathrm{R}^{\prime}{ }_{\mathrm{b}} \mathrm{S}\right)$, 
Einstein claims that it is only $\tau_{0}^{\prime}$ that is responsible for the bed load transport, and therefore $\tau_{0}^{\prime}$ and the corresponding $V_{*}^{\prime}$ and $R^{\prime}$ should be used in computing $\varphi$ and $\psi$ in Einstein's equation. However, in the use of $\tau_{0}^{\prime}$, the question arises about the method of separating $\tau_{0}^{\prime}$ from $\tau_{0}$.

Einstein and Barbarossa [3] have proposed a method for finding $V^{\prime \prime}{ }_{*}$ which corresponds to $\tau^{\prime \prime}{ }_{0}$. Using natural river data, they have prepared a curve showing the relationship between $\mathrm{V} / \mathrm{V}^{\prime \prime}$ * and $\left(\rho_{s}-\rho_{f} / \rho_{f}\right)\left(d_{3 \pi} / \mathrm{R}_{b}^{\prime} \mathrm{S}\right)$ in which $\mathrm{V}$ is the mean velocity of flow, $R_{b}^{\prime}$, is the hydraulic radius with respect to grain size, and $d_{35}$ is the size of material such that $35 \%$ of the material is finer than $d_{35}$. The subscript $b$ indicates that the hydraulic radius of the bed is used in the computations. This curve is shown in fig. 1. By using this graph, Einstein proposed the following procedure for computing $\mathrm{R}_{7}^{\prime}$ :

Step :

1. Find the hydraulic radius of the bed $R_{b}$ (othervise use $\mathbf{R}$ );

2. Assume $\mathbf{R}_{b}^{\prime}=\mathbf{R}_{b}$;

3. Calculate $\varphi^{\prime \prime}=\left[\left(\rho_{s}-\rho_{f}\right) / \rho_{f}\right]\left(d_{3 h} / \mathbf{R}_{b 3}^{\prime} \mathbf{S}\right)$;

4. Use curve in the fig. 1 in find $\mathrm{V} / \mathrm{V}^{\prime \prime}$;

5. Calculate $\mathrm{V}=5.75 \mathrm{~V}^{\prime} * \log _{10}\left(12.27 \mathrm{R}^{\prime}{ }_{10} x / d_{65}\right)$ in which $x=f\left(d_{f: 5} V_{*}^{\prime} / \nu\right)$ and $x=1$ for $\left(d_{65} / \delta\right)>5$;

6. Knowing $\mathrm{V}$ and $\mathrm{V} / \mathrm{V}^{\prime \prime}{ }_{*}, \mathrm{~V}^{\prime \prime}{ }_{*}$ and $\mathrm{R}^{\prime \prime}{ }_{\text {, }}$ are computed;

7. Compute new value of $\mathrm{R}_{b}^{\prime}=\mathrm{R}_{b}-\mathrm{R}_{b}^{\prime \prime}$;

8. Use this new value of $\mathrm{R}^{\prime}{ }_{l}$ and compute again $\mathbf{R}_{b}^{\prime \prime}$;

9. Try the next approximation.

A value of $V_{*}^{\prime}, R_{b}^{\prime}$ and $\tau_{0}^{\prime}$ obtained in this fashion should be used in Einstein's equation for finding the bed load transport. The following objections are raised against the use of $\mathrm{V}^{\prime}{ }_{*}$ in the hed load transport problems :

a) In developing the relationship between $\mathrm{V} / \mathrm{V}^{\prime \prime}$ * and $\psi^{\prime \prime}$, eq. (9) is used in order to find the shear resulting from grain roughness. This equation is true only for the non-movable bed. Its application to a movable bed in questionable. For example, eq (9) assumes that the Karman constant has a value 0.40 , while in actual case it is found to be a function of the flow conditions [4].

b) Einstein's and Barbarossa's plot of $\mathrm{V} / \mathrm{V}^{\prime \prime} *$ against $\psi^{\prime \prime}$ is not exact. Iwagaki [6], and recently Vanoni and Brooks [11] have shown that if the flume data are used to verify the foregoing relationship, a considerable scatter results. The authors have plotted data from various sources on fig. 1. This figure also shows much scatter. This discrepency may be due, at least in part, to the following two reasons :

1. The scale of irregularities on the bed of the flume may be different from the scale of irregularities in natural channels;

2. An important third variable such as Froude number, which might be significant, is omitted. In fact, the steepness of the dunes (height/length ratio) depends on $\tau^{*}$ and Froude number.

c) Since the computations of $V_{*}^{\prime}$ are based on the steps $a$ and $b$, values of $\mathrm{V}^{\prime}{ }_{*}$ are questionable. Also the successive approximation procedure used in finding values of $\mathrm{V}^{\prime}$ is time consuming.

For these reasons, the writers believe that the problem of bed load transport should be handled in a fashion different from that proposed by Einstein.

Variation of $\boldsymbol{q}_{\mathrm{B}}{ }^{*}$ with $\tau^{*}$.

Most of the data used for this analysis arc listed in reference [7]. The size range of the material used is from $0.486 \mathrm{~mm}$ to $15.49 \mathrm{~mm}$. The sediment transport as listed in the reference contains a small quantity of suspended load; bul since the size of the materials of the data used are relatively coarse, it is assumed that the rate of sediment transport as listed in the reference is the rate of bed load transport. This was confirmed by sample computations in the case of $0.786 \mathrm{~mm}$ diameter sediment. Shear and shear velocity with respect to the bed were used to compute the parameters $\tau^{*}$ and $q^{*}{ }_{B}$.

Fig. 2 shows the variation of $q^{*}{ }_{B}$ with $\tau^{*}$ for all these data. Observe that there is a great scatter for small values of $\tau^{*}$ and therefore for small values of $q^{*}$. As the parameter $\tau^{*}$ increases the scatter hecomes smaller and smaller.

In order to find the cause of this scatter, each point was labelled for the type of the bed regime-dune regime or plane bed regime.

A close study of fig. 2 reveals that the plane bed data have a tendency to fall on a single curve. It is Ingical that the dune hed data 


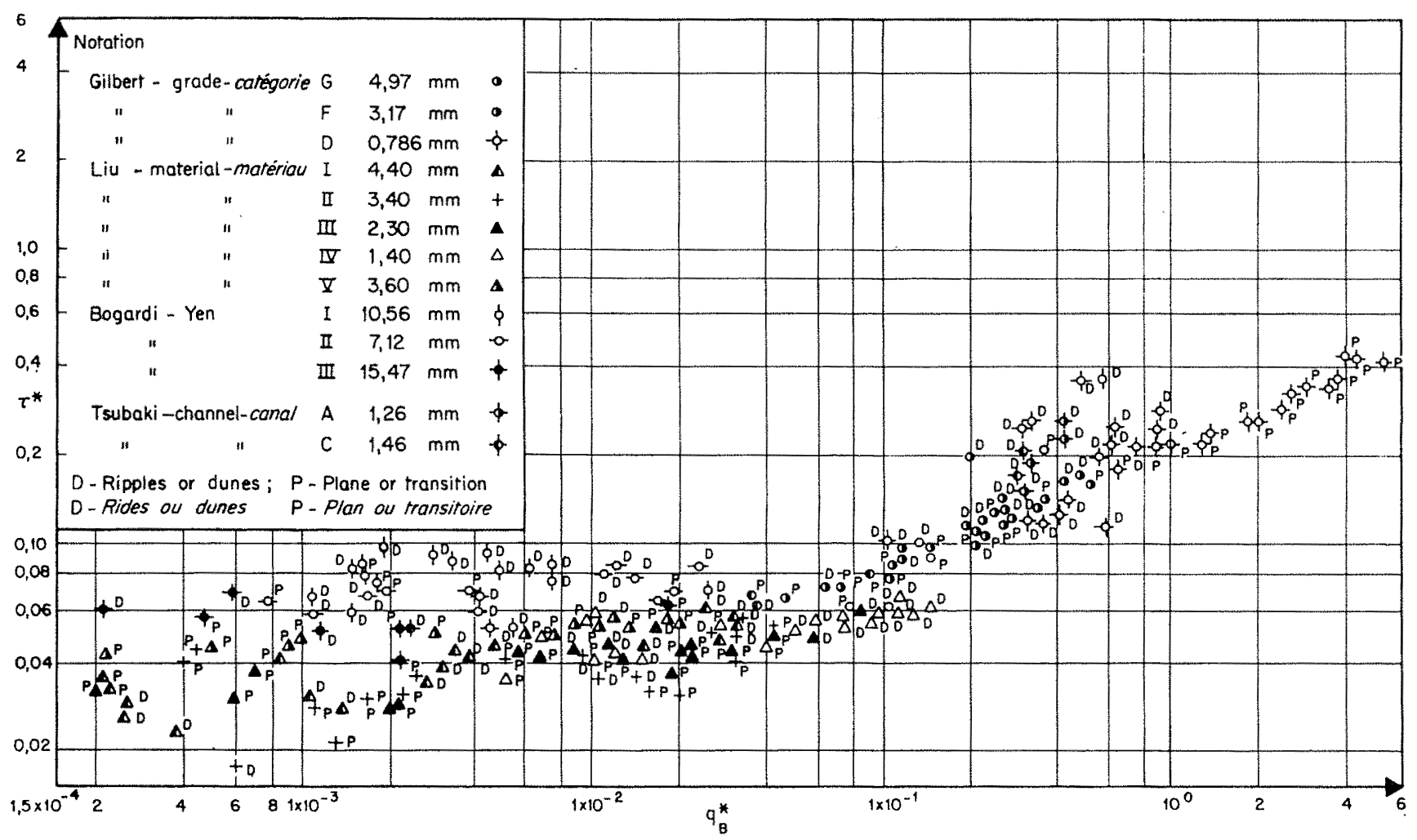

FIG. 2

Variation of $q^{*}$ with $\tau^{*}$ for plane-bed and dune-bed data.

Variation de $q_{\mathrm{r}}$ * anec $\tau^{*}$ pour fond plan et fond dunaire.

would not lie on the same curve as the plane bed data, since in the case of dume bed data, part of the total shear is used to overcome the resistance due to the bed irregularities. Therefore, less shear is available for the bed load transport. Hence the data are separated into plane bed data and dune bed data and are analysed separately.

\section{Variation of $\boldsymbol{q}_{\mathrm{B}} *$ with $\tau^{*}$ in the plane bed regime.}

Fig. 3 shows the variation of $q^{*}{ }_{\mathrm{B}}$ with $\tau^{*}$ in the plane bed regime. On the same figure are drawn the curves representing Einstein's equation and Kalinske's equation.

It can be seen that, even though the data do not follow either of the two equations, all the data for $\tau^{*}>0.06$ fall on a single curve. The data scatter to a large extent for the values of $\tau^{*}<0.06$.

The scatter of the data in fig. 3 for small values of $\tau^{*}$ seems to have a definite cause. A review of the bed load equations by investigators such as Du Boys, United States Waterways Experiment Station, and others reveals that their bed load equations can be put in the form :

$$
q^{*}{ }_{\mathrm{B}}=f\left\{\left(\tau^{*}-\tau^{*}{ }_{c}\right)^{m}\right\}
$$

in which $\tau_{c}^{*}=\tau_{c} /\left(\gamma_{s}-\gamma_{f}\right) d$ and $\tau_{c}$ is the eritical shear for a given size of bed material and $m$ is a constant. Shields work and Iwagaki's work [6] show that for the coarser material $\tau^{*}{ }_{0}$ attains an almost constant value of 0.05 . Therefore, in the case of coarser material, equation 10 reduces to the form :

$$
q_{\mathrm{B}}^{*}=f\left(\tau^{*}\right)
$$

For finer material however, $\tau^{*}{ }_{c}$ depends on $V_{*} d / v$ in which $v$ is the kinematic viscosity of the fluid, and therefore it is not constant. For this reason, the transformation of equation 10 into equation 1 is an approximation. This may explain the scatter near the lower end of the plot of $q^{*}{ }_{s}$ vs $\tau^{*}$ in the case of finer material. Furthermore, at larger values of $\tau^{*}, \tau^{*}{ }_{c}$ will be relatively small for finer material and therefore $\left(\tau^{*}-\tau_{0}^{*}\right) \approx \tau^{*}$. So, transforming equation 10 into equation 1 would introduce small error 
for larger value of $\tau^{*}$ even if the material is fine.

A part of this scatter at smaller values of $\tau^{*}$ can be also atributed to the inability to make accurate measurements of bed load under low shear stress.

Since neither Einstein's equation nor Kalinske's equation expresses the variation of $q^{*}{ }_{\mathrm{B}}$ with $\tau^{*}$ over a wider range of $\tau^{*}$, the solid line drawn through the data is proposed as a new means for evaluating the bed load transport in the plane bed regime. Thus knowing $\tau^{*}$, the bed load can be evaluated by use of the newly-proposed curve on fig. 3.

Variation of $q_{\mathrm{B}}{ }^{*}$ with $\tau^{*}$ in the dune bed regime.

Fig. 4 shows the variation of $\mathrm{q}^{*}{ }_{\mathrm{B}}$ with $\tau^{*}$ in the case when the bed is rough due to the formation of ripples and dunes. A glance at this figure reveals that there is no tendency for the data to fall on a single curve. The large variation indicates the possibility that in addition to $q^{*}$, and $\tau^{*}$, there must be a third dimensionless parameter which may govern the phenomenon of bed load transport.

Tsubaki and others [10] 1953, have shown that for equal values of $\tau^{*}$, the rate of bed load transport expressed as $q^{*}{ }_{B}$ is smaller in the dune regime than in the plane bed regime. In other words, formation of ripples and dunes on the bed reduces the rate of bed load transport. Therefore, the third parameter to be used on the plot of $q^{*}{ }_{\mathrm{B}}$ vs $\tau^{*}$ should be such that it expresses the rariation in the bed roughness.

After some preliminary studies it was found that the use of $\mathrm{V} / \mathrm{V}_{*}$ as the third parameter gives the best correlation. Therefore $\mathrm{V} / \mathrm{V}_{*}$ is plotted as the third variable on $q^{*}{ }_{B}$ vs $\tau^{*}$ plot on fig. 4, for which it is possible to draw line of constant values of $\mathrm{V} / \mathrm{V}_{*}$.

In the case of a straight alluvial channel, the total shear $\tau_{0}$ can be divided into two portions, as suggested by Einstein. These are the shear stress $\tau_{0}^{\prime}$ resulting from grain roughness and the

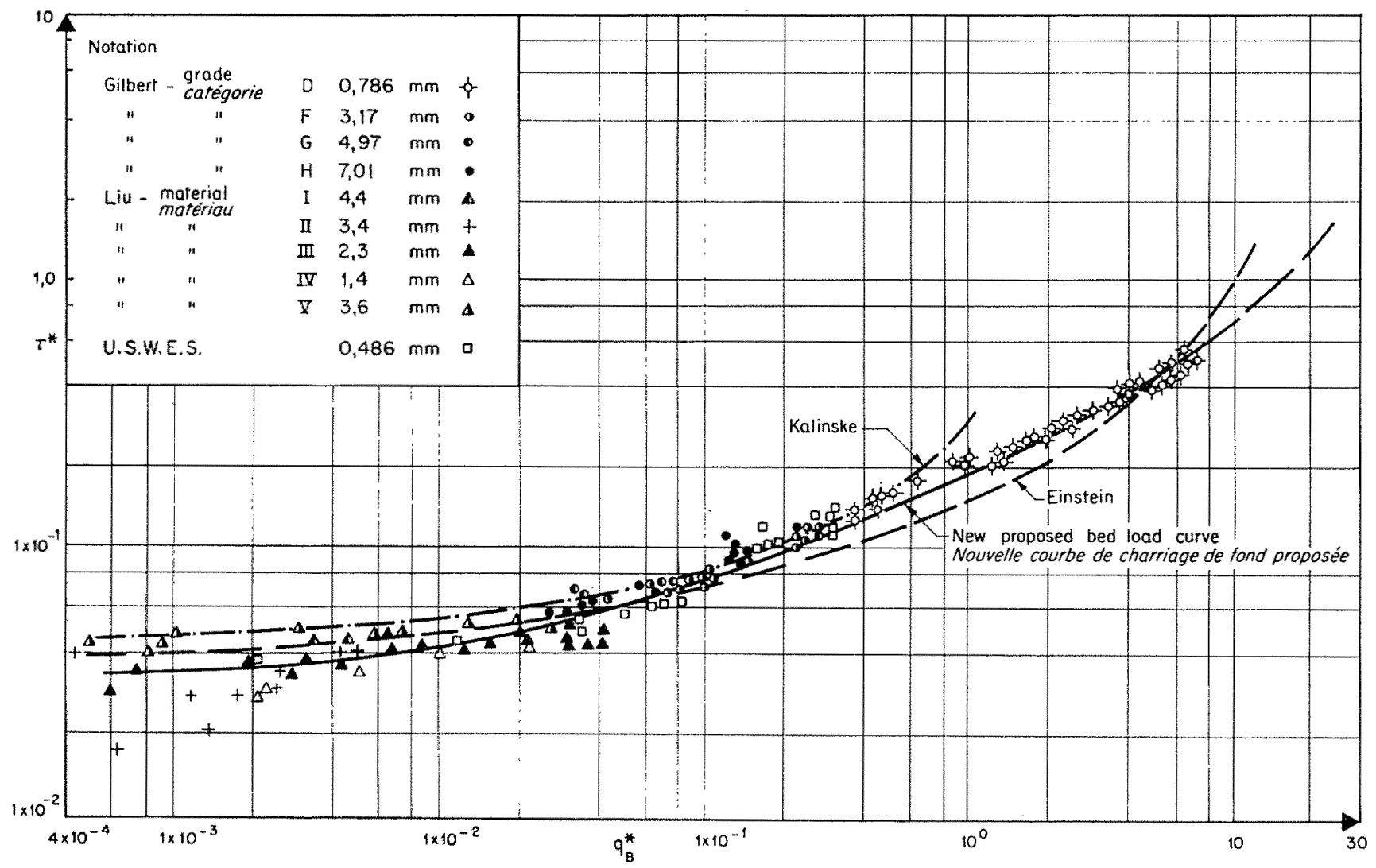

Fig. 3

Variation of $q \mathrm{~s}^{*}$ with $\tau^{*}$ for plane-bed data.

Variation de $q_{\mathrm{s}^{*}}$ avec $\tau^{*}$ pour un fond plan 


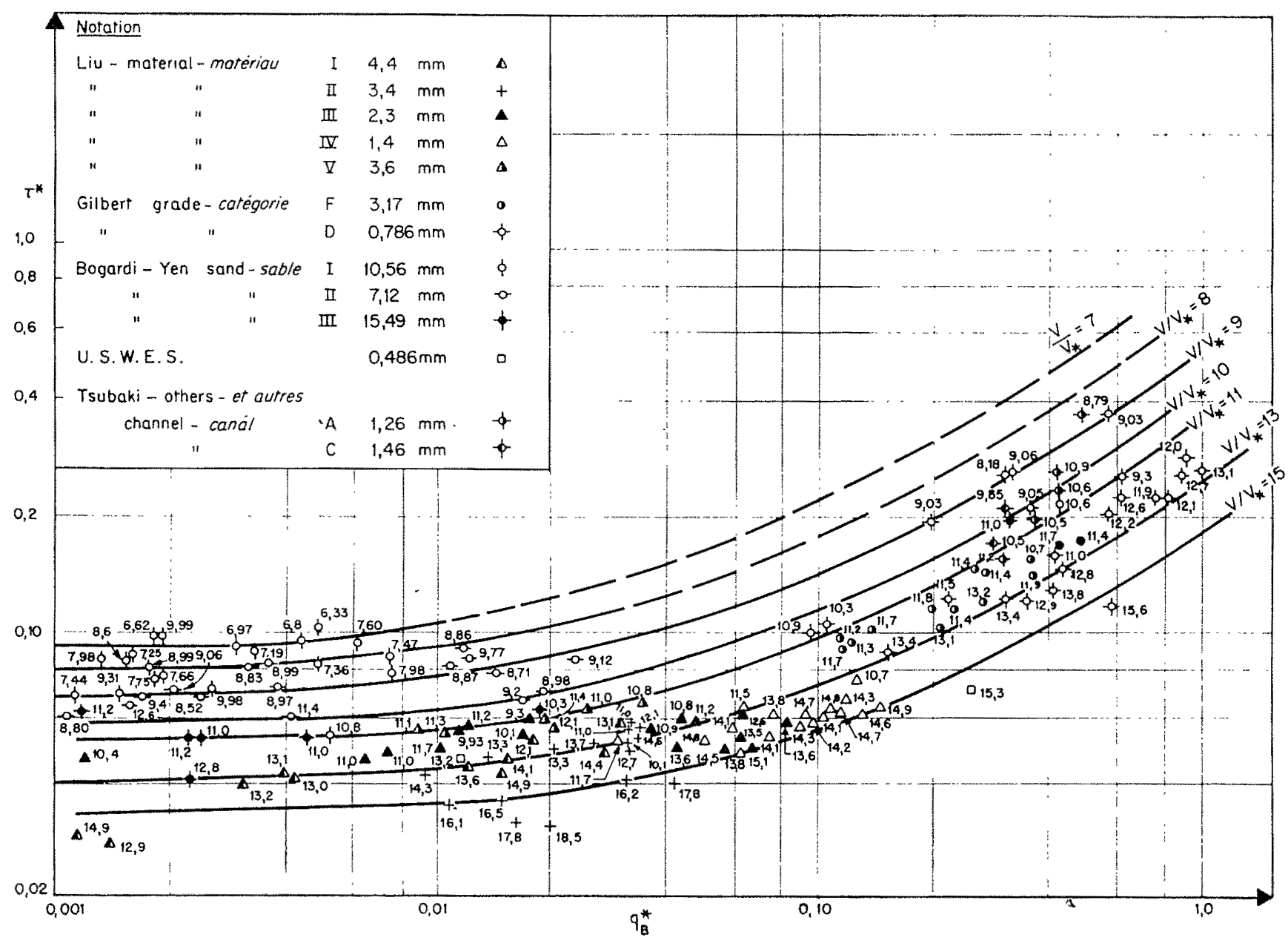

Fig. 4

Variation of $q^{*}{ }^{*}$ with $\tau^{*}$ for dune-bed data,

Variation de $q_{\mathrm{B}}{ }^{*}$ avec $\tau^{*}$ pour un fond dunaire.

additional shear stress $\tau^{\prime \prime}{ }_{0}$ resulting from the bed irregularities. The term $\tau^{\prime \prime}{ }_{0}$ corresponds to the form drag on the dunes developed on the bed. The index of these bed irregularities, and also the index of the value $\tau^{\prime \prime}{ }_{0}$ can be the dimensionless Chezy coefficient, or in other words $\mathrm{V} / \mathrm{V}_{*}$.

As the value of $\mathrm{V} / \mathrm{V}_{*}$ decreases, or in other words as the bed becomes rougher, there will be smaller shear available for the bed load trans. port. Therefore the rate of bed load transport will decrease.

Fig. 4 is thus capable of representing the variation in $q_{* \mathrm{~B}}$ in the dune bed regime, as the shear and the resistance to flow change. Also, it helps to give a physical feeling to the problem of bed load transport. Furthermore, the development of fig. 4 has greatly facilitated the evaluation of the rate of bed load transport, since it is no longer necessary to go through a tedious process of suc- cessive approximations in finding Einstein's $V^{\prime}{ }_{*}$.

Use of figures 3 and 4 can now be made to compute the rate of bed load transport when $V$, $\mathrm{D}, \mathrm{S}, d$ and the regime of flow are known.

\section{Determination of the regime of flow.}

The writers have recently $[4,5]$ proposed a criterion for determining the regimes of flow. In addition to the flume data, this criterion also holds good for the field data. It is proposed that this criterion be used to determine the regime of flow. Fig. 5 gives this criterion.

\section{Acknowledgments}

The study reported in this paper is part of the Doctoral Dissertation submitted by the first wri- 
ler under the general supervision of the second writer, to Colorado State University, Fort Collins (U.S.A.). Suggestions and the advice given by
Dr. Iwagaki, Assistant Professor of Civil Engineering at Kyoto University, Japan, are greatly appreciated.

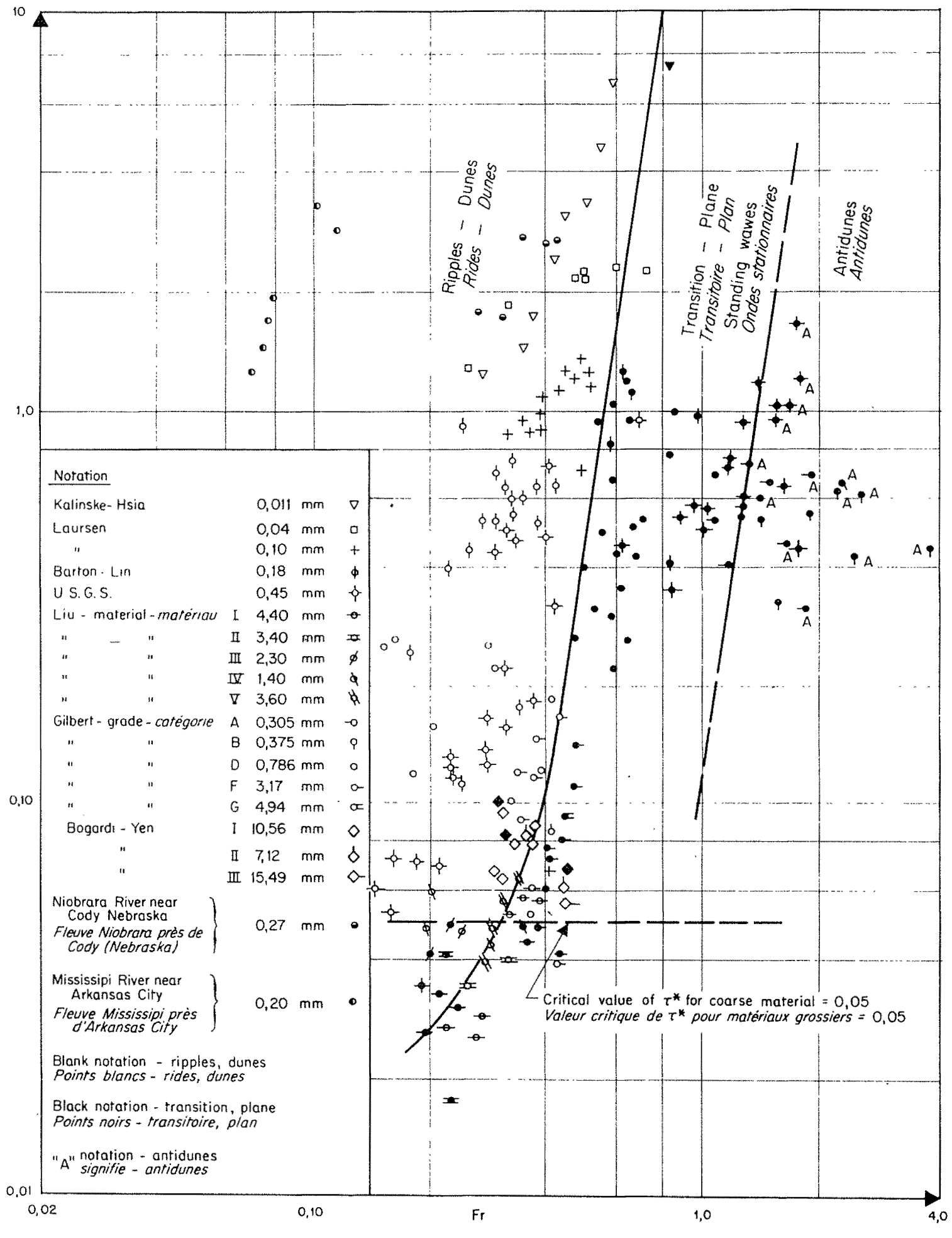

Fig. 5

Criteria for regimes of flow in alluvial channels.

Critères des régimes d'éconlement en chenaux alluviaux. 


\section{BIBLIOGRAPHY}

[1] Ning Chren. - The present status of research on sediment transport. A.S.C.E. Transactions, 121:833$883,1956$.

[2] H. A. Einstein. - The bed load function for sediment transportation in open channel flows. U.S. Soil Conservation Service, Technical bulletin No. 1026, Sept. 1950, 71 p.

[3] H. A. Einstein and N.L. Barbarossa. - River channel roughness. A.S.C.F. Transactions, $117: 1121-1146$ 1942.

[4] R.J. Garde. - Total sediment transport in alluvial channels. Colorado State University, Fort Collins, U.S.A. Ph. D. thesis. Jan. 1959.

[5] R.J. Garde and M. L. Albertson, - Characteristics of bed forms and regimes of flow in alluvial channels. Civil Engineering Section, Colorado State University, Fort Collins, U.S.A. 1959, 18 p.

[6] Ishinara, Tozmo, editor. - Applied Hydraulics. Series II, Vol. 1. Maruzen Book Co., p. 33, 37, 38, 1957. In Japanese.
[7] J. W. Johnson. - Laboratory investigations on bed load transportation and bed roughness. U.S. Soil Conservation Service, SCS-TP-50, May 1943, 116 p.

[8] A. A. Kalinske. - Movement of sediment as bed load in rivers. A.G.U., Transactions, 28:615-620, Aug. 1947.

[9] H. Rouse, editor. - - Engineering Hydraulics, 1950, p. 797.

[10] T. Tsubaki, T. Kawasum and T. Yastutom. - On the influence of sand ripples upon the sediment transport in open channels. Kyushu University, Research Institute of Applied Mechanics, Report, 1953. 2 (8) :241-256.

[11] V.A. VANONI and N.H. Brooks. - Laboratory studies of the roughness and suspended load of alluvial streams. California Institute of Technology, Sedimentation Laboratory, Pasadena. Report No. E-68, Dec. 1957,127 p.

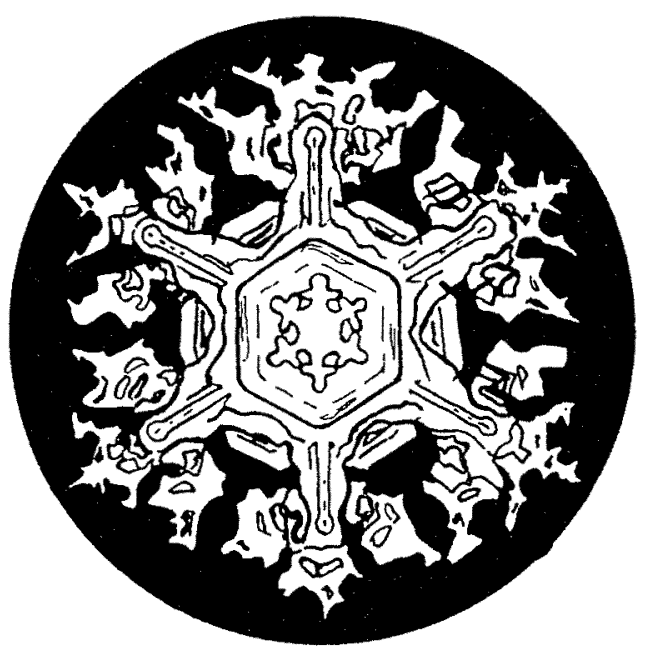




\section{Le charriage de fond dans les chenaux alluviaux}

\author{
RAM J. GARDE \\ MAITUE DE CONFÉRENCES DE GÉNIE GIVIL \\ (MĚCANIQUE DES FLUIDES) \\ A L'UNIVERSITÉ DE ROORKEe, ROORKEE (INDE)
}

PAR

ET

\section{L. ALBERTSON}

professeur de GÉNIE GIVIL

ET DIRECTEUR DE LA FONDATION DE RECHERCHES

A L'UNIVERSITÉ DE L'ÉTAT DU COLORADO, FORT COLLINS (U.S.A.)

English text p. $274^{(*)}$

\begin{abstract}
Les auteurs soumettent les données existant sur le charriage de fond des matériaux à une nouvelle analyse, et montrent que les lois régissant le transport des matériaux par charriage dépendent beaucoup de la nature du fond. Ils indi-
\end{abstract}

quent des relations fonctionnelles pour, respectivement, un fond plan et un fond dunaire. L'application des relations proposées est relativement aisée.

\section{INTRODUCTION}

La possibilité de déterminer le débit solide global dans un chenal alluvial, pour des caractéristiques hydrauliques données, est, pour diverses raisons, d'un haut intérêt pour les ingénieurs hydrauliciens et d'irrigation. Suivant le mode de transport des matériaux, le transport solide global peut être considéré comme comprenant trois phénomènes séparés : le transport en suspension, le transport en saltation, et le transport par charriage de fond proprement dit. Le charriage de fond proprement dit comprend les matériaux roulant ou glissant le long du fond, avec lequel ils restent en contact quasi-permanent. La saltation comprend les grains «sautillant 》 le long du fond, ou bien ceux mis en mouvement directement ou indirectement par d'autres grains rebondissants. Le transport en suspension concerne les matériaux se déplaçant en suspension dans le fluide. Cependant, la fraction des matériaux transportée en saltation est généralement très faible; de plus, il est généralement très difficile de définir nettement la limite séparant les (*) Se reporter au texte anglais pour les figures et la bibliographie. phénomènes de saltation et de charriage en contact avec le fond. Le charriage de fond proprement dit, et le transport par saltation, seront, pour ces raisons, considérés comme constituant ensemble le charriage de fond.

Des essais ont été effectués à plusieurs reprises depuis 1879, pour établir des méthodes permettant d'évaluer le transport par charriage de fond. Les équations de charriage de fond de du Boys, Shields, Chang, McDougall et O'Brien, Meyer-Peter, Kalinske, Einstein, et d'autres auteurs, ont résulté de ces essais. Ces équations se renferment dans deux catégories générales :

a) Equations empiriques (Chang, McDougall, Meyer-Peter, et d'autres);

b) Equations semi-théoriques (Du Boys, Shields, Kalinske, Einstein, et d'autres).

\section{Comparaison entre les équations de Meyer- Peter, de Kalinske et d'Einstein.}

Bien que toutes ces équations se présentent sous des formes différentes, il est intéressant de 
noter qu'elles peuvent cependant, pour la plupart, être exprimées sous la forme générale :

$$
\frac{q_{\mathrm{B}}}{\mathrm{V}_{*} \gamma_{s} d,}=f\left(\frac{\tau_{0}}{\left(\gamma_{s}-\gamma_{f}\right) d}\right),
$$

ou, en substituant

$$
\begin{gathered}
\tau^{*}=\frac{\tau_{0}}{\left(\gamma_{s}-\gamma_{f}\right) d} \quad \text { et } \quad \tau^{*}=\frac{q_{\mathrm{B}}}{V_{* \gamma_{\mathrm{s}}} d} \text { on obtient : } \\
q^{*}{ }_{\mathrm{B}}=f\left(\tau^{*}\right)
\end{gathered}
$$

dans laquelle :

$\tau_{0}=$ Contrainte moyenne de cisaillement sur le fond;

$q_{\mathrm{B}}=$ Débit par charriage de fond en poids, par unité de largeur du canal, par unité de temps;

$d=$ Granulométrie moyenne du matériau de fond;

$\mathrm{V}_{*}=$ Vitesse de cisaillement $\left(=\sqrt{\left.\tau_{c} / \rho_{f}\right)}\right.$;

$\rho_{f}=$ Densité du fluide;

$\gamma_{s}, \gamma_{f}=$ Poids spécifiques, respectivement, des matériaux, et du fluide.

Ainsi, en considérant l'équation de MeyerPeter [1] :

$$
\varphi=\left(\frac{4}{\psi}-0,188\right)^{3 / 2}
$$

dans laquelle :

$$
\psi=\frac{\rho_{s}-\rho_{f}}{\rho_{f}} \cdot \frac{d}{\mathrm{RS}},
$$

$R$ étant le rayon hydraulique, $S$ la pente de la ligne de charge et $i_{s}$ la densité des matériaux solides, et :

$$
\varphi=\frac{q_{B}}{\gamma_{R}}\left(\frac{\rho_{f}}{\rho_{s}-\rho_{f}}\right)^{1 / 2}\left(\frac{1}{g d^{3}}\right)^{1 / 2} .
$$

On peut exprimer $\psi$ et $\varphi$ de la manière suivante :

$$
\begin{aligned}
\psi=\frac{\rho_{s}-\rho_{f}}{\rho_{f}} \frac{d}{\mathrm{RS}} & =\frac{g\left(\rho_{s}-\rho_{f}\right)}{g_{\rho_{f}}} \frac{d}{\mathrm{RS}} \\
& =\frac{\left(\gamma_{s}-\gamma_{f}\right) d}{\tau_{0}}=\frac{1}{\tau^{*}},
\end{aligned}
$$

et :

$$
\begin{aligned}
\varphi=\frac{q_{\mathrm{B}}}{\gamma_{s}}\left(\frac{\rho_{\mathrm{f}}}{\rho_{s}-\rho_{f}}\right)^{1 / 2}\left(\frac{1}{g d^{3}}\right)^{1 / 2} & \\
& =\frac{q_{\mathrm{B}}}{\mathrm{V}_{*} \gamma_{s} d} \cdot \frac{\mathrm{V}_{*} d \rho_{f}^{1 / 2}}{\left(\rho_{s}-\rho_{f}\right)^{1 / 2}} \cdot\left(\frac{1}{g d^{3}}\right)^{1 / 2 .}
\end{aligned}
$$

d'où :

$$
\varphi=q_{\mathrm{B}}^{*} \tau^{* 1 / 2}
$$

En introduisant ces valeurs de $\psi$ et de $\varphi$ dans l'équation 2, on obtient l'équation de MeyerPeter sous la forme :

$$
q_{\mathrm{B}}^{*} \tau^{* 1 / 2}=\left(4 \tau^{*}-0,188\right)^{3 / 2} .
$$

L'équation d'Einstein pour le charriage de fond, s'appliquant au cas d'un matériau de fond uniforme, peut s'écrire sous la forme:

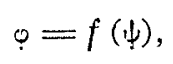

dans laquelle $\varphi$ et $\psi$ sont définis comme précédemment. Mais, puisque o et $\psi$ peuvent être exprimés en fonction de $q^{*}$ et de $\tau^{*}$, l'équation d'Einstein pour le charriage de fond peut également s'écrire sous la forme :

$$
q^{*}{ }_{\mathrm{B}}=f\left(\tau^{*}\right) \text {. }
$$

Enfin, l'équation de Kalinske pour le charriage de fond [8] peut être écrite sous la forme :

$$
\frac{q_{\mathbf{B}}}{\boldsymbol{V}^{*} \gamma_{s} d}=f\left(\frac{\tau_{c}}{\tau_{0}}\right) \text {, }
$$

dans laquelle $\tau_{c}=12 \mathrm{~d}$. On peut donc également écrire cette équation (7) sous la forme:

$$
q^{*}{ }_{\mathrm{B}}=f\left(\tau^{*}\right) \text {. }
$$

Au lieu d'étudier séparément le comportement de ces trois équations par rapport à certaines données, les auteurs en ont tracé les courbes correspondantes en fonction des axes $q^{*}{ }_{\mathrm{n}}$ et $\tau^{*}$. Des graphiques analogues sont également donnés par Iwagaki [6] et Rouse [9], bien que celui de Rouse ait été présenté d'une manière légèrement différente.

\section{Observations complémentaires sur l'équation d'Einstein.}

Einstein $[2,3]$ a distingué entre deux parties du cisaillement moyen sur le fond $\tau_{0}$ :

$$
\tau_{0}=\tau_{0}^{\prime}+\tau^{\prime \prime}{ }_{0}
$$

avec :

$\tau_{0}^{\prime}=$ la contrainte de cisaillement qui résulterait de la résistance seule du grain sur le fond plan, et

$\tau^{\prime \prime}{ }_{0}=$ la contrainte de cisaillement complémentaire, due aux irrégularités du fond, telles que dunes ou barres sableuses.

D'après Einstein, le transport par charriage de fond serait uniquement provoqué par $\tau_{0}^{\prime} ; \tau_{0}^{\prime}$ et les $\mathrm{V}^{\prime}{ }_{*}$ et $\mathrm{R}^{\prime}$ correspondants devraient donc être utilisés pour calculer les valeurs $\varphi$ et $\psi$ dans son équation. Pour l'utilisation de $\tau_{0}^{\prime}$, ce- 
pendant, il se pose le problème de séparer $\tau_{0}^{\prime}$ de $\tau_{0}$.

Einstein et Barbarossa [3] ont proposé une méthode pour la détermination de $\mathrm{V}^{\prime \prime} *$ corres-

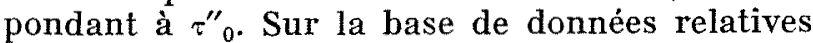
à une rivière naturelle, ils ont établi une courbe mettant en évidence la relation entre $\mathrm{V} / \mathrm{V}^{\prime \prime}{ }_{*}$ et $\left(\rho_{s}-\rho_{f}\right) / \rho_{f}\left(d_{35} / \mathrm{R}_{b}^{\prime} \mathrm{S}\right)$ dans laquelle $\mathrm{V}$ est la vitesse moyenne d'écoulement, $\mathrm{R}_{b}^{\prime}$ est le rayon hydraulique par rapport à la granulométrie, et $d_{35}$ est la granulométrie du matériau, telle que $35 \%$ de ce matériau soient plus fins que $d_{35}$. L'indice $b$ signifie que le rayon hydraulique du fond est utilisé dans les calculs. Sur la base de cette courbe (présentée dans la figure 1), Einstein a proposé la méthode suivante pour calculer $\mathbf{R}_{b}^{\prime}$ :

Etapes :

1 : O'n détermine le rayon hydraulique $d u$ fond $R_{\imath}$ (sinon, on utilise $R$ );

2: On suppose que $\mathrm{R}_{b}^{\prime}=\mathrm{R}_{b}$;

$3:$ On calcule $\psi^{\prime \prime}=\left[\left(\rho_{s}-\rho_{f}\right) / \rho_{f}\right]\left(d_{35} / \mathrm{R}_{b}^{\prime} \mathrm{S}\right)$;

4: Sur la base de la courbe de la figure 1, on détermine $\mathrm{V} / \mathrm{V}^{\prime \prime} *$;

5 : On calcule $\mathrm{V}=5,75 \mathrm{~V}^{\prime} \log _{10}\left(12,27 \mathrm{R}_{b}^{\prime} x / d_{35}\right)$ où $x=f\left(d_{65} \mathrm{~V}_{*}^{\prime}\right) / y$, et $x=1$ pour $\left(d_{65} / \delta\right)>5$;

6 : Connaissant $\mathrm{V}$ et $\mathrm{V} / \mathrm{V}^{\prime \prime}{ }_{*}$, on calcule $\mathrm{V}^{\prime \prime}{ }_{*}$ et $\mathrm{R}^{\prime \prime}{ }_{b}$

7 : On calcule une nouvelle valeur pour :

$$
\mathbf{R}_{b}^{\prime}=\mathbf{R}_{b}-\mathbf{R}_{b}^{\prime \prime} \text {; }
$$

8: Fn utilisant cette nouvelle valeur de $\mathrm{R}_{b}^{\prime}$, on recalcule $\mathrm{R}^{\prime \prime}{ }_{b}$.

9: On essaye l'approximation suivante.

Pour déterminer le transport par charriage de fond, on fera intervenir une valeur de $V^{\prime}, R_{b}^{\prime}$ et $\tau_{0}^{\prime}$ ainsi obtenue, dans l'équation d'Einstein.

Les objections suivantes s'élèvent contre l'utilisation de $V^{\prime} *$ pour la résolution des problèmes de transport par charriage de fond :

a) En développant la relation entre $V / V^{\prime \prime}$ * et $\psi^{\prime \prime}$, on utilise l'équation (9) afin de déterminer le cisaillement dû à la rugosité des grains. Mais cette équation n'est valable que pour un fond non affouillable, et l'extension de cette validité à un fond affouillable est douteuse. Par exemple, l'équation (9) admet une valeur. de 0,40 pour la constante de Karman, alors que cette valeur se révèle, dans un cas réel, comme étant fonction du régime d'écoulement [4].

b) La courbe d'Einstein et de Barbarossa exprimant $\mathrm{V} / \mathrm{V}^{\prime \prime}{ }_{*}$ en fonction de $\psi^{\prime \prime}$ n'est pas exacte. Iwagaki [6], et depuis, Vanoni et Brooks [11], ont démontré que la confron- tation de résultats d'essais en canal avec des valeurs calculées d'après cette relation met en évidence une dispersion considérable. Les auteurs du présent rapport ont tracé les courbes des données provenant de diverses sources sur la figure 1 , qui présente également une forte dispersion. Cet écart peut être imputé, du moins en partie, aux deux raisons suivantes :

1. L'échelle des irrégularités sur le fond $d u$ canal peut être différente de celle des canaux naturels;

2. Il n'a pas été tenu compte d'une troisième variable importante, celle que le nombre de Froude, bien que cette variable puisse ètre significative. Or, la raideur et la pente des dunes (rapport longueur/hauteur) dépend, en fait, à la fois de $\tau_{*}$ et du nombre de Froude.

c) Etant donné que les calculs de $V^{\prime} *$ sont basés sur les étapes $a$ et $b$, les valeurs de $V^{\prime}{ }_{*}$ sont peu sûres. De plus, le procédé de détermination des valeurs de $V_{*}^{\prime}$ par approximations successives nécessite un temps appréciable.

Les auteurs pensent, pour ces diverses raisons, qu'il serait préférable d'aborder le problème du transport par charriage de fond par une méthode autre que celle d'Einstein.

\section{Variation de $q_{\mathrm{B}}{ }^{*}$ en fonction de $\tau^{*}$.}

La plupart des données utilisées pour la présente analyse sont indiquées dans la référence [7]. La granulométrie du matériau utilisé varie entre $0,486 \mathrm{~mm}$ et $15,49 \mathrm{~mm}$. Le débit solide, tel qu'indiqué dans la référence, contient une faible fraction de particules en suspension, mais puisque les matériaux faisant l'objet des données uti. lisées sont relativement gros, le débit solide mentionné dans la référence est considéré comme représentant le débit de charriage. Cette hypothèse s'est vérifiée par des calculs pour des matériaux de $0,786 \mathrm{~mm}$. Le taux et la vitesse de cisaillement relatifs au fond ont servi au calcul des paramètres $\tau^{*}$ et $q^{*}$.

La figure 2 montre la variation de $q^{*}$ B en fonction de $\tau^{*}$, pour toutes ces données. On constate une forte dispersion aux faibles valeurs de $\tau^{*}$, donc également aux faibles valeurs de $q^{*}{ }_{\mathrm{B}}$. Cette dispersion diminue progressivement, à mesure que le paramètre $\tau^{*}$ croît.

Afin de déterminer la cause de cette dispersion, on a indiqué pour chaque point le type de régime de fond correspondant (régime à fond dunaire ou plan).

L'examen approfondi de la figure 2 montre que les données pour un fond plan tendent à s'ali- 
gner sur une seule courbe. Il est tout à fait logique de s'attendre à ce que les données pour un fond dunaire ne se trouvent pas sur la même courbe que celles du fond plan, car, dans le cas du fond dunaire, une partie du cisaillement total sert à vaincre la résistance due aux irrégularités du fond, et il s'ensuit qu'une partie moins importante du cisaillement reste disponible pour le charriage. C'est pour cette raison que l'on a distingué entre, d'une part, les données relatives à un fond plan, et, d'autre part, celles pour un fond dunaire, et qu'elles ont été analysées séparément.

\section{Variation de $q_{\mathrm{B}}{ }^{*}$ en fonction de $\tau *$, pour un régime de fond plan.}

La figure 3 montre la variation de $q_{* \mathrm{~B}}$ en fonction de $\tau^{*}$ pour un régime de fond plan, ainsi que les courbes exprimant les équations d'Einstein et de Kalinske.

Bien que les données ne soient conformes, soit à l'une, soit à l'autre de ces équations, on constate cependant que toutes les valeurs pour $\tau^{*}>0,06$ s'alignent sur une courbe unique. Une assez forte dispersion apparaît pour les valeurs correspondant à $\tau^{*}<0,06$.

La dispersion des données de la figure 3 aux faibles valeurs de $\tau^{*}$ paraît être imputable à une cause bien déterminée. L'examen des équations de transport par charriage proposées par des au. teurs tels que Du Boys, l'Tnited States Waterways Experiment Station, el d'autres, montre qu'elles peuvent être écrites sous la forme :

$$
q^{*}{ }_{\mathrm{B}}=f\left\{\left(\tau^{*}-\tau^{*}\right)^{m}\right\}
$$

dans laquelle $\tau^{*}{ }_{c}=\tau_{c} /\left(\gamma_{s}-\gamma_{f}\right) d$, et $\tau_{c}$ étant le cisaillement critique, pour une granulométrie donnée du matériau de fond, et $m$ étant une constante. Dans leurs recherches, Shields et Iwagaki [6] montrent que $\tau^{*}{ }_{c}$ atteint une valeur quasi-constante de 0,05 , pour les matériaux relativement gros. On peut donc, pour ces gros matériaux, réduire l'équation 10 à la forme :

$$
q^{*}{ }_{\mathrm{B}}=f\left(\tau^{*}\right) \text {. }
$$

Par contre, pour les matériaux plus fins, $\tau^{*}{ }_{c}$ n'est pas une constante, étant fonction de $V * d / v$ ( $\nu=$ la viscosité cinématique du fluide); il en résulte que la transformation de l'équation (10) en l'équation (1) ne peut être qu'une approximation. Ceci pourrait expliquer la dispersion constatée à l'extrémité inférieure de la courbe $q^{*}{ }_{\mathrm{L}}$ en fonction de $\tau^{*}$, pour les faibles granulométries. En outre, $\tau_{*_{c}}$ sera relativement petit pour les matériaux fins aux grandes valeurs de $\tau_{*}$, de sorte que $\left(\tau^{*}-\tau_{c}^{*}\right) \approx \tau^{*}$. La transformation dans ces conditions, de l'équation (10) en l'équation (1), donnerait donc lieu à un faible écart aux valeurs relativement élevées de $\tau^{*}$, même pour un matériau fin.

On peut également attribuer une partie de cette dispersion constatée aux faibles valeurs de $\tau^{*}$, à l'impossibilité de mesurer, avec une précision suffisante, le débit de charriage correspondant aux contraintes de cisaillement peu élevées.

Puisque ni l'équation d'Einstein, ni celle de Kalinske, n'expriment la variation de $q^{*}{ }_{\mathrm{B}}$ en fonction de $\tau^{*}$ pour une gamme de valeurs de $\tau^{*}$ plus élendue, les auteurs proposent la courbe en trait plein de la figure 3 comme pouvant servir de nouvelle base d'évaluation du transport par charriage, en régime de fond plan. Connaissant alors $\tau^{*}$, on peut évaluer le débit de charriage en employant la courbe nouvellement proposée de la figure 3 .

\section{Variation de $q_{1}{ }^{*}$ en fonction de $\tau^{*}$, en régime de fond dunaire.}

La figure 4 montre la variation de $q^{*}$ en fonction de $\tau^{*}$, pour le cas d'un fond rendu rugueux par la formation de rides et de dunes. On roit immédiatement que les points ne tendent guère à s'aligner sur une courbe unique. La grande dispersion des points laisse entrevoir la possibilité, qu'en plus de $q^{*}$; et de $\tau^{*}$, un troisième paramètre sans dimensions doive vraisemblablement influer sur le phénomìne du transport par charriage de fond.

Tsubaki et d'aulres auteurs [10] ont montré en 1953 que, pour des valeurs égales de $\tau^{*}$, le débit de charriage de fond exprimé par $q^{*}{ }_{\mathrm{B}}$ est plus faible en régime dunaire qu'en régime de fond plan. Autrement dit, la formation des rides et des dunes diminue le débit de charriage. Il s'ensuit que le troisième paramètre à introduire dans la courbe de $q^{*}$, en fonction de $\tau^{*}$, doit être tel qu'il puisse exprimer la variation de la rugosité du fond.

11 s'est révélé, à la suite de quelques éludes préliminaires, que l'adoption de $\mathrm{V} / \mathrm{V}_{*}$, comme troisième paramètre, permetlail d'obtenir la meilleure corrélation. On a, par conséquent, introduit $\mathrm{V} / \mathrm{V}_{*}$ comme troisième variable de la relation de $q^{*}$ s en fonction de $\tau^{*}$ de la figure 4 , variable pour laquelle il est possible de tracer des courbes de valeurs égales de $\mathrm{V} / \mathrm{V}_{*}$.

Dans le cas d'un chenal alluvionnaire rectilisne, on peut distinguer entre deux parties du cisaillement total $\tau$, ainsi que l'a proposé Finstein. Ces deux parties sont : la contrainte de cisaillement $\tau_{0}^{\prime}$, due à la rugosité des grains, el la contrainte de cisaillement complémentaire $\tau{ }^{\prime \prime}{ }_{0}$, 
due aux irrégularités de fond. Le terme $\tau_{0}^{\prime \prime}$ correspond à la traînée due à la forme des dunes sur le fond. Le coefficient sans dimension de Chézy, c'est-à-dire $\mathrm{V} / \mathrm{V}^{*}$, peut être adopté comme indice à la fois de ces irrégularités du fond, et de la valeur $\tau^{\prime \prime}{ }_{0}$.

A mesure que la valeur de $V / V_{*}$ diminue, c'està-dire lorsque le fond devient plus rugueux, le cisaillement disponible pour le transport par charriage de fond diminue également, et, par conséquent, le débit de charriage.

La figure 4 peut ainsi représenter les varialions de $q^{*}$ en régime de fond dunaire, en fonclion des variations du cisaillement et de la résistance à l'écoulement. Elle permet également de donner un sens physique au problème du transport par charriage de fond. Enfin, elle rend beau. coup plus aisée l'évaluation du débit de charriage, puisqu'elle élimine toute nécessité de déterminer le $\mathrm{V}^{\prime}{ }_{*}$ d'Einstein par un procédé laborieux d'approximations successives.

Les figures 3 et 4 permettent de calculer le débit solide, pour des valeurs connues de V, D, S, $d$, et pour un régime d'écoulement donné.

\section{Détermination des régimes d'écoulement.}

Les auteurs du présent rapport ont dernièrement $[4,5]$ proposé un critère pour la détermination des régimes d'écoulement. Ce critère est non seulement valable pour les données provenant d'essais dans des canaux expérimentaux, mais il s'applique tout aussi bien aux données relatives aux cours d'eau naturels. Les auteurs proposent l'utilisation de ce critère (indiqué su: la figure 5) pour déterminer le régime d'écoulement.

\section{Remerciements}

L'étude faisant l'objet du présent rapport représente une partie de la thèse de doctorat présentée, sous la supervision de M. A. Albertson, par Ram J. Garde à l'Université de l'Etat du Colo. rado, à Fort Collins (U.S.A.). Les auteurs ont été très sensibles aux suggestions et conseils si aimablement apportés par M. le $D^{r}$ Iwagaki, Professeur adjoint de Génie civil à l'Université de Kyoto (Japon).

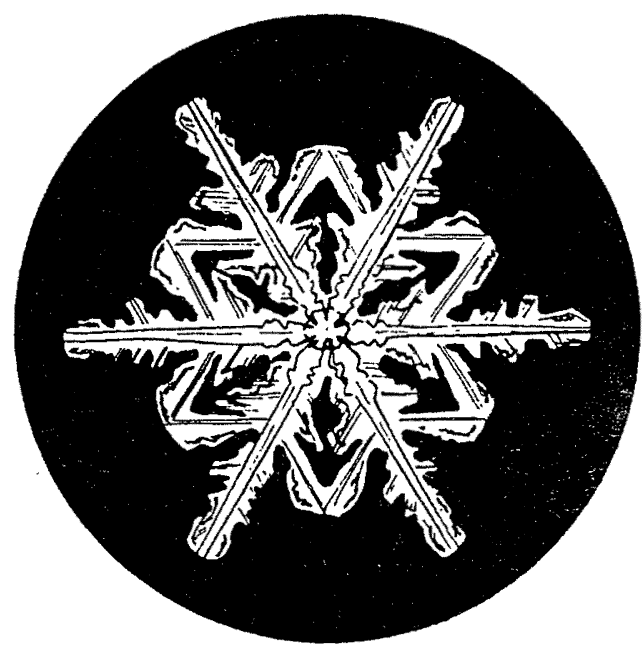

